JMKSP (Jurnal Manajemen, Kepemimpinan, dan Supervisi Pendidikan) Volume 6 Issue 2 (2021) Page 318-335

ISSN 2614-8021 (Online) 2548-7094 (Print)

\title{
Analysis on Portfolio Assessment Leadership Management in Universitas PGRI Palembang
}

\author{
Neta Dian Lestari ${ }^{1}$, Diana Widhi Rachmawati ${ }^{2}$, Boby Agus Yusmiono ${ }^{3}$ \\ 1,2,3 Universitas PGRI Palembang \\ Corresponding Author E-mail: neta_obyta@yahoo.com
}

Received 25 May 2021; Revised 5 June 2021; Accepted 11 June 2021

\begin{abstract}
Portfolio assessment is an approach that is not new anymore, portfolios are exposed by educational experts to be implemented in educational institutions. In addition to the new assessment approach, the old portfolio assessment approach can be used. The application of portfolio assessment has not been optimally applied to learning activities in Higher Education. Research objectives were to analyze the application of portfolios in Leadership Management courses in the Primary School Teacher Education Study Program Universitas PGRI Palembang. We used descriptive method. The results of data analysis carried out in the study concluded that the application of the portfolio was very good in terms of student activity in learning, assignments and final test results in the Very Active or Very Good categories. Learning activities were $51.61 \%$ very active, $38.71 \%$ very good assignments and the final test was $54.84 \%$ very good. Based on the results of this study, the application of portfolio assessment is expected to be an alternative strategy for educators in the learning process to improve learning outcomes, motivate learning and as an effort to improve the quality of student learning.
\end{abstract}

Keyword: Assessment, Portfolio, Management, Leadership.

\section{Introduction}

As educators, they must be able to properly carry out the learning process in online classes or online learning, which is able to deliver students to have 
knowledge and skills in learning. The spirit of education as a form of improving the quality of education itself, through the role of an educator as a personal improvement effort built by any student. The learning approach developed by educators seems to be unable to appreciate individual student differences. This fact can be seen that there are still many educators who apply classical teaching, where educators teach in the same way for all students in the learning process.

This makes it easier for students who are still unable to master the lesson which should make it easier for them to understand the lesson under these circumstances. Then with this classical teaching system, it makes them reluctant or lazy to be able to understand more deeply about the lesson, even though the lesson will be easy to understand if the educator can implement a teaching system that attracts students' attention to arouse their curiosity, and arouse creativity. The student.

According to Winkel in Riyanto (2010) a psychic activity that takes place in an active interaction with the environment, which resulted in changes in the knowledge, understanding, skills, attitudes and values. These changes are relatively constant and lasting. Knowing the learning achievement in online classes, a learning activity is needed that can measure the success of students, educators must be able to present a pleasant atmosphere and be able to develop students' creativity.

The implementation of the Education Process Standards has a very important component, because the successful implementation of the education process is very important. The success of the implementation of the spearhead education process is very dependent on educators.

Efforts to improve the quality of education, which should start from improving the abilities and innovations of an educator. Students must have the ability, one of which is skill in designing learning strategies that are in accordance with the objectives and competencies to be achieved with certain strategies. As educators we must be optimal in preparing teaching equipment, According to Lestari, ND, \& Pratiwi, N. (2019). As a professional educator, we must have completeness in learning, both syllabus, Semester Learning Plan and Teaching Materials. Teaching Materials is a collection of materials prepared by lecturers based on syllabus. Teaching materials can also be a benchmark of the quality of learning materials provided by lecturers.

Portfolio assessment in the curriculum is one that is suggested to be followed up and suggested to be carried out by educators in online lessons or classes. The assessment approach has been used for a long time, but according to some experts' 
priority, portfolio assessment is an approach that is not new anymore. The application of portfolio assessment has not been optimally applied to learning activities in tertiary institutions. Several countries have made extensive use of portfolios in the world of education both in regional and national assessments. Portfolio assessment is used in the classroom or online learning, but it is not as complicated as that used for portfolio assessment nationally. Comparison in portfolio assessment through quantitative data such as test scores, grades, ratings and percentiles. Portfolio assessment is an alternative to improve the ability of students through feedback evaluation and self-assessment (Suprana and Hatta, 2006).

In the application of the curriculum used by tertiary institutions, portfolio assessment has not been so applied in learning activities. Portfolio assessment which is an online class-based assessment through SISFO E-Learning, Zoom Meeting, Google Classroom and other applications that can assist online classroom-based educator assessments. The online class is one of the answers to the demands which are expected to improve competence and learning outcomes of the Leadership Management course, which is a general course with the course code MKUP241 of 2 credits. Based on the description above, researchers are interested in implementing online class-based portfolio assessments to improve student learning outcomes and student learning activities in the Leadership Management course for the 2020/2021 academic year.

\section{Literature Review}

\section{Portfolio}

According to Surapranata and Hatta (2006) a portfolio can be interpreted as a collection of evidence or learning outcomes of students that show the efforts, developments, learning achievements of students from time to time and from one subject to another. Portfolios are also very influential as a tool to improve education that allows students to participate more in the learning process. Meanwhile, portfolio is a personal collection of the work of a student (individual) that reflects the level of achievement, learning activities, strengths, and the best work of a student. Due to its sustainability, the collection which is the result of this work is dynamic because it always grows and develops (Muslich, 2009).

According to Surapranata and Hatta (2006) whereas evidence or portfolio production results are made into four types, namely (1) the work of learners 
(artifacts), which is the work of learners produced in the classroom; (2) Reproduction, namely the work of students who are done outside the classroom; (3) attestations, namely questions and results of observations made by eductors or other parties regarding students; (4) production, namely the work of students who are specially prepared for portfolios.

According to Nurhay ati, FR, \& Sumbawati, MS (2014) e-portfolios or electronic portfolios or digital portfolios or web folios or e-folios, are collections of works in electronic form that are compiled by the user as a form of self-development notes. The term e-Portfolio generally refers to an electronic tool that supports the existing objective, pedagogical and valuation concepts of a paper-based portfolio.

Based on the above opinion, portfolio assessment is a collection of individual student work done outside the online classroom, which can show student participation and interest in the learning process and can show creative student learning outcomes.

\section{Portfolio Assessment}

Portfolio research is a series of assessments that can assist educators in assessing learning in an online classroom. Assessment is one of the activities carried out to measure and assess the level of curriculum achievement and the success or failure of the learning process. Assessment is also used to determine the strengths and weaknesses that exist in the learning process, so that it can be used as a basis for decision making, for example whether the learning process is good and can be continued or still needs improvement and completion (Surapranata and Hatta, 2006).

According to Muslich (2009) Portfolio is a collection of work of a student in a certain period. This collection of works describes the level of competence achieved by a student. Portfolios can be used to assess the development of students' abilities. Meanwhile, according to Surapranata and Hatta, (2006) portfolio assessment is one type of assessment used in online class-based assessments and has an optimal meaning in seeing the achievement of learners' learning competencies. Classroom-based assessment online is the assessment carried out by educators in the context of the learning process. Class-based portfolio assessment is a series of processes for gathering information from student learning outcomes compiled by educators in determining the level of achievement and mastery of students towards predetermined educational goals. The educational objectives are 
competency standards, basic competencies, and learning achievement indicators contained in the curriculum.

Then in the implementation of this portfolio assessment, educators conduct an assessment of the work of students, especially in Leadership Management courses carried out by individual students. Papers referred to in the assessment of the portfolio is in the form of collection notes, exercises, and manufacture of props arranged Students individually and siste Matis on a particular matter in $\mathrm{m}$ ata lecture Leadership Management. Then after work (notes, exercises and props) the student made before students explaining the work that they have made. Meanwhile, the educator is in charge of assessing the students' work using the existing portfolio assessment format.

According to Surapranata and Hatta (2006) this portfolio is the use of written assessments, projects, products, and record of performance. Portfolios in classroom assessments can be used to achieve several goals (1) appreciating the developments experienced by students; (2) documenting the learning process that is taking place; (3) paying attention to the best work performance of students; (4) reflect on the ability to take risks and carry out experimentation; (5) increase the effectiveness of the teaching process; (6) exchange information with parents of students and other educators; (7) fostering and accelerating the growth of positive self-concepts in students; (8) increase the ability to do self-reflection; and (9) helping students in formulating goals.

Based on the above definition, portfolio assessment is an assessment carried out by educators in the learning process of a set of students' work within a certain period of time, to determine the level of achievement and mastery of students towards predetermined educational goals.

\section{Portfolio Assessment Functions and Objectives}

Portfolio function according to Surapranata and Hatta (2006) to determine the development of students 'knowledge and abilities in certain subjects, as well as the growth of students' abilities. Portfolio as a follow-up material of the work of educators in preparing student assessments, so that educators and students have the opportunity to develop their abilities. According to Muslich (2009), a portfolio for the purpose of assessment is to obtain information about the growth/progress of student learning or the potential for growth/progress in learning. The portfolio is used by educators to improve and to obtain data on student or student learning 
progress which can be processed into final grades/KHS or descriptions of student competencies in certain courses.

\section{Advantages and Weaknesses of Portfolio Assessment}

According to Surapranata and Hatta (2006), as a new paradigm, the portfolio has advantages and disadvantages in its implementation in the classroom. The advantages of using portfolio appraisal include 1) change in assessment predigm; 2) accountability; 3) students as individuals and the active role of students; 4) identification 5) the involvement of parents/guardians of parents in the community; 6) self-assessment; 7) flexible assessment; 8) responsibility together; 9) justice; 10) assessment criteria. While the weaknesses of using a portfolio assessment include 1) extra time; 2) reliability; 3) the final achievement; 4) topdown; 5) skepticism; 6) nothing new; 7) criteria for assessment and analysis; 8) application in educational institutions; 9) formal complete and detailed assessment; and 10) storage area.

Online class-based e-portfolios have an advantage over paper-based portfolios. According to Orsini Jones \& De (2007) the advantages are (a) The paper-based portfolio system cannot accommodate an increase in the range of assessments and is inflexible; (b) Currently, universities have made extensive use of eLearning; (c) E-Portfolios are easily published; (d) E-Portfolio is a basis that can be used to link the entire curriculum; (e) E-Portfolios are generally designed to support Personal Development Planning and enhance reflective and independent skills practice; (f) the E-Portfolio is user-centered; (g) E-Portfolios allow discussion with a number of parties".

\section{Portfolio assessment criteria}

According to Surapranata and Hatta (2006) criteria of assessment on the portfolio relies heavily on the characteristics of the basic competencies that have been determined. Several variations of the use of the assessment criteria can use 1) Poor, 2) Good, 3) Very Good, as below: 
TABLE I

ASSESSMENT CRETERIA ON PORTFOLIO

(EXAMPLE 1)

\begin{tabular}{|c|c|c|c|}
\hline Basic Competitions & \multicolumn{3}{|l|}{$\begin{array}{l}\text { Name: } \\
\text { Date: }\end{array}$} \\
\hline Indicator & \multicolumn{3}{|l|}{ ASSESSMENT : } \\
\hline & Not so good & Good & Very well \\
\hline Accomplished Through & \multirow{5}{*}{\multicolumn{3}{|c|}{ Educator's Comments }} \\
\hline All Classes Help Educators & & & \\
\hline - Small group & & & \\
\hline - Alone & & & \\
\hline $\begin{array}{l}\text { - Comments People Parents / Guardians } \\
\text { People Old }\end{array}$ & & & \\
\hline
\end{tabular}

Surapranata and Hatta (2006)

Or 1) Very Bad, 2) Bad, 3) Fair, 4) Very Good and 5) Very Good.

TABLE II

ASSESSMENT CRETERIA ON PORTFOLIO

(EXAMPLE 2)

\begin{tabular}{|c|c|c|c|c|c|}
\hline Basic Competitions & $\begin{array}{l}\text { Name } \\
\text { Date : }\end{array}$ & & & & \\
\hline Indicator & ASSESSME & & & & \\
\hline & ugly once & Ugly & Moderate & Good & $\begin{array}{l}\text { Good } \\
\text { Once }\end{array}$ \\
\hline Accomplished Through & \multirow{5}{*}{\multicolumn{5}{|c|}{ Educator's Comments }} \\
\hline All Classes Help Educators & & & & & \\
\hline - Small group & & & & & \\
\hline - Alone & & & & & \\
\hline $\begin{array}{l}\text { - Comments People Parents / } \\
\text { Guardians People Old }\end{array}$ & & & & & \\
\hline
\end{tabular}

Surapranata and Hatta (2006)

The criteria for assessment are very much dependent on how the educator assesses the portfolio that is their assessment. Assessment criteria related to making a synopsis or summary of the story include:

TABLE III

ASSESSMENT CRETERIA

\begin{tabular}{|c|l|c|}
\hline No. & Kreteria & Score \\
\hline 1. & Systematics & $0-20$ \\
\hline 2. & $\begin{array}{l}\text { The suitability of the story content with the book title is } \\
\text { scored }\end{array}$ & $0-35$ \\
\hline 3. & Plot & $0-15$ \\
\hline 4. & EYD & $0-20$ \\
\hline 5. & Essay Shape and Neatness & $0-10$ \\
\hline
\end{tabular}

Surapranata and Hatta (2006)

\section{Portfolio Assessment Format}

The assessment format presented by educators can be used in assessing the achievement of students' abilities according to what is determined by the 
curriculum.The assessment format for the Leadership Management course uses numbers 1 to 10 .

TABLE IV

PORTFOLIO ASSESSMENT F ORMAT

\begin{tabular}{|c|c|c|c|c|c|c|c|c|c|c|}
\hline Basic Competitions & \multicolumn{10}{|c|}{$\begin{array}{l}\text { Name : } \\
\text { Date } \quad:\end{array}$} \\
\hline Indicator & \multicolumn{10}{|c|}{ ASSESSMENT: } \\
\hline & 1 & 2 & 3 & 4 & 5 & 6 & 7 & 8 & 9 & 10 \\
\hline Accomplished Through & \multirow{5}{*}{\multicolumn{10}{|c|}{ Educator's Comments }} \\
\hline All Classes Help Educators & & & & & & & & & & \\
\hline - Small group & & & & & & & & & & \\
\hline -Alone & & & & & & & & & & \\
\hline $\begin{array}{c}\text { - Comments People Parents / } \\
\text { Guardians People Old }\end{array}$ & & & & & & & & & & \\
\hline
\end{tabular}

Surapranata and Hatta (2006)

According Muhibbin Shah (2009) factors that affect learners can our bed will be three kinds, namely: 1) internal factors, the state/physical and spiritual conditions student, 2) external factors, the environmental conditions around the student; and 3) the learning approach factor, the type of learning efforts of students which include strategic efforts and methods used by students to carry out learning material activities subject matter.

\section{Online Learning (Online Class)}

According to Dewi (2020) online learning makes students have the freedom to study time, can study anytime, anywhere, and anyone. According to Fitriyani, Y., Fauzi, 1., \& Sari, MZ (2020) online learning is an educational innovation that involves elements of information technology in learning. Online lectures are lectures that use applications in the form of WhatssApp (WA), google classroom, and quizizzz (Naim, Ngainun. 2020).

From the description above can be concluded Learning online is learning mengg $\mathrm{u}$ nakan technological innovation and memanfaatka $\mathrm{n}$ applications that can be done anytime, anywhere and anyone so as to facilitate the learning of students without reducing the learning activities directly .

\section{Research Methods}

The research was done (Arikunto, 2013) with the steps preparation and implementation. In the preparation include 1) creating lesson plan and teaching materials for leadership management courses; 2) make practice questions; 3) make 
a research sheet for each student's portfolio; and 4) creating a folder for storing student work results. In the implementation 1) preliminary selection of the concepts to be studied; 2) prepare online classroom settings and tools as needed; 3) explain the criteria that will be used as a reference in portfolio assessments based on indicators during teaching and learning activities and apply these criteria together with students; describe the material to be delivered; 4) give assignments to students which will be the result of student learning and tests at the end of each meeting to understand the material that has been delivered during the learning process; 5) assessing the work of students by using a portfolio assessment sheet; 6) returns the work of students and the assessment format for the portfolio that has been assessed for later comments by their respective parents; 7) save student work results and portfolio assessments into the folder of each student.

\section{Data Collection Techniques}

We used documentation, according to Arikunto (2013) the documentation technique is a search for data about things or variables in the form of notes, transcripts, books, newspapers, magazines, inscriptions, meeting minutes, leggers, a genre, and so on". The documentation data collection technique is meant, the author collects data from books and notes related to the titles presented. In this data collection technique is used to determine the state of the college where the researcher is researching, such as the number of students, the Leadership Management curriculum and others.

Then we used observation, observation is an indirect observation or data collection or it can be said that it is a non-test such as an interview. In this study, non- test data collection was carried out by observing the activities or activities of students in online classes. Observations or observations are made during the learning process in online classes on the observation sheet where the assessment indicators consist of oral, visual, writing, listening, listening and work-making activities and metrics. The observation sheet will be given a chsck list on the descriptor of each Indicator that appears in the activities of students.

This research observation is used to obtain data and observations of the assessment of participants' learning activities during the learning process using existing indicators. The indicators and descriptor of the activeness of learners obtained are Indicator 1: Viewing activity; Indicator 2: Listening activity; Indicator 3: Writing activity; Indicator 4: Essay activity 


\begin{tabular}{|c|c|c|c|c|c|c|c|c|c|c|c|c|c|}
\hline \multirow[t]{2}{*}{ No. } & \multirow{2}{*}{$\begin{array}{c}\text { Name of } \\
\text { Partiicipant } \\
\text { learners }\end{array}$} & \multicolumn{3}{|c|}{ Indicator 1} & \multicolumn{3}{|c|}{ Indicator 2} & \multicolumn{3}{|c|}{ Indicator 3} & \multicolumn{3}{|c|}{ Indicator 4} \\
\hline & & 1 & 2 & 3 & 1 & 2 & 3 & 1 & 2 & 3 & 1 & 2 & 3 \\
\hline $\begin{array}{l}1 . \\
2 . \\
N\end{array}$ & & & & & & & & & & & & & \\
\hline & amount & & & & & & & & & & & & \\
\hline
\end{tabular}

(Purwanto, 2009)

The last we used test, according to Arikunto (2013) a test is a series of questions or exercises that are used to measure the knowledge, intelligence, abilities, or talents possessed by an individual or group. After the application of the portfolio is carried out in a Competency Standard, then the test is carried out. The purpose of the test is to determine the learning outcomes of students after the implementation of the portfolio assessment in one Competency Standard. The test is given at the end of one Basic Competency and after submitting one Competency Standard. The form of the test itself is in the form of a written test or essay test for each student who is given at the end of each meeting.

Observation data were analyzed using quantitative descriptive. Observation data was carried out by calculating the frequency descriptor based on each indicator, then presented with the formula:

$N P=\frac{R}{S M} \times 100 \quad$ (Purwanto, 2009:102)

Information:

$\mathrm{NP}=$ Percent value sought and disclosed

$\mathrm{R}$ = raw score obtained by students

$\mathrm{SM}=$ ideal score of the test in question

To see the activeness of students in implementing this portfolio assessment, it can be seen with the following assessments: 
TABLE VI

CATEGORIES OF KEAK TIFAN

\begin{tabular}{|c|c|}
\hline Score & Category \\
\hline $86-100$ & Very Active \\
$76-85$ & Active \\
$60-75$ & Enough Active \\
$55-59$ & Less Active \\
$=54$ & Very Less Active \\
\hline
\end{tabular}

(Purwanto , 2009: 103)

Portfolio assessment is carried out after the data is collected, the educator will analyze it to see the influence and learning outcomes of students during the implementation of the portfolio assessment. By looking at the comparison of the results of the application of the portfolio assessment with the results of the final test of the application of the portfolio assessment. Calculating the average test score of students with the formula: $\mathrm{X}=\frac{\Sigma x_{i}}{\mathrm{n}}($ Sudjana, 2015)

TABLE VII

PREDICATE LEARNING OUTCOMES

\begin{tabular}{|c|c|}
\hline Score & Predicate \\
\hline $8.5-10$ & Very good \\
$7.0-8.4$ & Good \\
$5.5-6.9$ & Enough \\
$4.5-5.4$ & Less \\
$0-4.4$ & Very Less \\
\hline \multicolumn{2}{|c|}{ ( Sudjana, 2015:67) } \\
\hline
\end{tabular}

\section{Results and Discussion}

Course Management Leadership with Code MKUP241, application portfolio assessment is an application of the newly applied in Semester 4 (Even). Therefore, before the research is carried out, researchers especially have to tell students how the implementation of this portfolio assessment learning takes place, especially the learning is done online. The stages of implementation in portfolio assessment research were

The first meeting

At this first meeting, researchers introduced themselves first so that the learning process could run well and get to know each other both to researchers and students, in this case students. Then accompanied by making observations of the activeness of students in the online class through observation sheets assisted by 
friends who act as observers. Furthermore, explaining the meaning of the application of portfolio assessment to students so that when carrying out the teaching and learning process activities and when conducting portfolio assessments it can be carried out well too.

In this meeting, the researcher started the learning activity by first showing the portfolio assessment format to the students and explaining the criteria used as a reference in the portfolio assessment adjusted to the indicators in the material or subject at each meeting. As well as jointly assigning scores to each existing criterion.

After the above activities were carried out, the next activity was to tell the material to be taught at this first meeting, namely about the differences and equations of sociology and anthropology, culture using the educational interaction method. Researchers also take learning steps such as giving motivation and apperception. After giving motivation and apperception to students, the researcher explains to the students about the material, then the researcher concludes the discussion of the material and then assigns assignments to students to be done using portfolio assessments.

Students who have worked on the assignment are then submitted to the researcher to be assessed according to the predetermined assessment of several existing criteria, after being assessed by the researcher, then the portfolio assessment sheet is given to the parents of each student to provide comments or responses to the results of his child's work through notes and exercises that have been assessed by the researcher first.

From the results of observations at the first meeting, there were only 28 out of 31 students in the experimental class who gave the portfolio assessment sheet to their respective parents/guardians, the rest were only 3 students who did not provide the results of the portfolio assessment to their parents.

Second meeting

At this second meeting the researcher no longer explained the portfolio assessment format to students, but the researcher immediately provided the material content on Social Mobility which will be discussed at this second meeting. However, previously the researcher gave the students apperception about the courses that had been studied in the previous week so that what was taught in the last week was not simply forgotten by the students. 
The method used in the second meeting was not much different from the method used in the first meeting. After the material is delivered by the student, the researcher provides the questions that the student will work on to complete the portfolio assessment that is being carried out. And not much different from the first meeting as well, at this second meeting after the assignment was done then the students collected the results of the notes and assignments to the researcher to be assessed according to the existing criteria in the application of portfolio assessment then given them back to students to be given to parents.

From the observations of this second meeting, there were 28 out of 31 students who gave the results of the portfolio assessment to their parents. The remaining only 3 people did not provide the portfolio assessment to their parents.

\section{Third Meeting}

At this third meeting, the researcher gave the students first perception before continuing the material to be taught next, namely materials about Education and Development. And not much different from the first and second meetings, after explaining the material that has been taught by students, students are given assignments to work on then assessed by researchers after that then given back to the parents to give comments on the portfolio assessment sheet which has been assessed in advance by the researcher. From the results of the observation of the third meeting, all 31 students gave the results of the portfolio assessment to their respective parents.

Fourth Meeting

At the fourth meeting or the last meeting, the researcher held a final test after all the material was delivered to the students which was done in an essay.

\section{Data Description}

The research data were obtained from observation data and learning outcomes which were carried out for 4 meetings and attended by 31 students. The data in the study were obtained from observational data through observations during the process of implementing portfolio assessment in online classes. Meanwhile, observations were made 3 times during the implementation of this portfolio assessment as well. Then at the 4th meeting a test was carried out to determine the learning outcomes of students with the presence of this portfolio assessment in the Leadership Management course and in the subject matter of preparing the 
management of the supplies supply card in semester 4 . The test data is obtained after the implementation of this portfolio assessment application process for each student where the test is the result of the individual student.

Observational Data Analysis

Observations are carried out during the teaching and learning process, namely 3 observations in 4 meetings. The observation sheet contains 4 indicators and each indicator consists of 3 descriptions. In this case the researcher observes all activities and activities of students during the application of this portfolio assessment. The results of this observational study are to see the level of student activeness in the process of applying the portfolio assessment. To see the level of student activeness during the implementation of the portfolio assessment 3 times, it can be seen in the following table:

TABLE VII I

STUDENT ACTIVITY LEVELS WITH APPLICATION PORTFOLIO ASSESSMENT

\begin{tabular}{|c|c|c|c|c|c|c|c|}
\hline \multirow[t]{2}{*}{ No. } & \multirow[t]{2}{*}{ Score } & \multicolumn{3}{|c|}{$\begin{array}{c}\mathrm{F} \\
\text { Meeting }\end{array}$} & \multirow[t]{2}{*}{$\begin{array}{l}\text { Aver'age } \\
\text { (F) }\end{array}$} & \multirow[t]{2}{*}{$\%$} & \multirow[t]{2}{*}{ Category } \\
\hline & & 1 & 2 & 3 & & & \\
\hline 1. & $86-100$ & 13 & 15 & 20 & 16 & 51.61 & Very Active \\
\hline 2. & $76-85$ & 8 & 7 & 9 & 8 & 25.81 & Active \\
\hline 3. & $60-75$ & 4 & 4 & 2 & 3 & 9.68 & Enough Active \\
\hline 4. & $55-59$ & 3 & 2 & - & 2 & 6.45 & Less Active \\
\hline 5. & $=54$ & 3 & 3 & - & 2 & 6.45 & Very Less Active \\
\hline & & 31 & 31 & 31 & 31 & $100 \%$ & \\
\hline
\end{tabular}

Based on the data from the observations in the table above, it is analyzed that the application of the student activity portfolio is very good, seen from the highest value of $51.61 \%$. The results of the training of each individual student can be seen in the table below: 
TABLE IX

RESULTS OF STUDENT TRAINING ON APPLICATION PORTFOLIO ASSESSMENT

\begin{tabular}{|c|c|c|c|c|c|c|c|}
\hline \multirow[t]{2}{*}{ No. } & \multirow[t]{2}{*}{ Score } & \multicolumn{3}{|c|}{$\begin{array}{c}\mathrm{F} \\
\text { Meeting }\end{array}$} & \multirow[t]{2}{*}{$\begin{array}{l}\text { Average } \\
\text { (F) }\end{array}$} & \multirow[t]{2}{*}{$\%$} & \multirow[t]{2}{*}{ Category } \\
\hline & & 1 & 2 & 3 & & & \\
\hline 1. & $8,5-10$ & 7 & 11 & 18 & 12 & 38.71 & Very good \\
\hline 2. & $7.0-8.4$ & 9 & 11 & 13 & 11 & 35.48 & Good \\
\hline 3. & $5.5-6.9$ & 7 & 9 & - & 5 & 16.13 & Enough \\
\hline 4. & $4.5-5.4$ & 8 & - & - & 3 & 9.68 & Less \\
\hline 5. & $0-4.4$ & - & - & - & - & - & Very Less \\
\hline & & 31 & 31 & 31 & 31 & $100 \%$ & \\
\hline
\end{tabular}

Based on the table of average student learning outcomes during the teaching and learning process in the application of portfolio assessment for 3 times application, from these data there is the highest student average score, which is in the very good category of $38.71 \%$.

\section{Test Data Analysis}

The test conducted by the researcher at the 4th meeting was the Essay written test, with the following results:

TABLE X

RESULTS STUDENT TRAINING ON APPLICATION

PORTFOLIO ASSESSMENTT

\begin{tabular}{|c|c|c|c|c|}
\hline No. & Score & F & $\mathbf{\%}$ & Category \\
& & & & \\
\hline 1. & $8,5-10$ & 17 & 54.84 & Very good \\
2. & $7.0-8.4$ & 8 & 25.81 & Good \\
3. & $5.5-6.9$ & 6 & 19.35 & Enough \\
4. & $4.5-5.4$ & - & - & Less \\
5. & $0-4.4$ & - & - & Very Less \\
\hline \multicolumn{4}{|r|}{} \\
\hline
\end{tabular}

Based on the table of test results at the fourth meeting the highest percentage was in the Very Good category, amounting to 54.84\%.

The application of the portfolio that was applied during 4 meetings was $86 \%$ and the rest was influenced by other factors. The implementation of portfolio assessment is progressing well and has successfully implemented the researchers feel this portfolio in the course of Management Leadership. Based on the activities of students in the application of portfolio assessment during the teaching and learning process, it plays a very good role, which is seen in the implementation of 
the first, second and third meetings, there is an increase in the value of students in training assessments after the subject matter is given.

The increase in student activity in the PGSD FKIP Study Program at Universitas PGRI Palembang can be seen at the first meeting of very active students, there were 13 students, 8 students were active, 4 students were quite active, 3 students were less active, and 3 students were very less active. Then in the second meeting 15 students were very active, 7 students were active, 4 students were quite active, 2 students were less active, and 3 students were very less active. While at the third meeting there were 20 very active students, 9 active students, 2 students who were quite active, less active and very less active. With the average percentage is Highly Active Sebes ar 51.61\%, Active amounted to 25.81 , please Active amounted to $9.68 \%$, Less Active amounted to $6.45 \%$ and Very Less Active amounted to $6.45 \%$.

The increase in the value of the assignment that the researcher gave at each meeting was clear, namely, at the first meeting there were 7 very good students, 9 good students, 7 good enough students, 8 bad students, none very bad. Then the second meeting was 11 very good students, 11 good students, 9 good enough students, not very good and very bad none. While at the third meeting there were 18 very good students, 13 good, good enough, not good, and not very good students. With an average percentage of $38.71 \%$ (Very Good), 35.48\% (Good), $16.13 \%$ (Good Enough), 9.68\% (Not Good), and in the category (Not Good) $0 \%$ or None.

The results of the study were based on the results of the test analysis in the form of Essay questions, the application of the portfolio was successfully applied. It was seen from the highest percentage of $54.84 \%$ in the Very Good category.

\section{Conclusion}

Based on the results of data analysis carried out in this study, it can be concluded that the application of the portfolio is very good in terms of student activity in learning, assignments and final test results in the Very Active or Very Good categories. Learning activities were $51.61 \%$ very active, $38.71 \%$ very good assignments and the final test was $54.84 \%$ very good. In the implementation of this research, there were weaknesses that were encountered by researchers when the research was taking place, the suggestions in this study are the application of portfolio assessment is something that is not new in the world of education but educators rarely use it, especially a lecturer, therefore the application of portfolio 
assessment is expected to be an alternative strategy in the learning process to improve learning outcomes and as an effort to improve student quality. This portfolio assessment is also expected to be able to motivate students to increase activeness in learning, results in learning and make the learning atmosphere less boring, especially in theoretical lessons (leadership management).

\section{Acknowledgment}

We would like to thank the Universitas PGRI Palembang for providing motivation and support so that this research can be completed. Hopefully this research will have a good use, both for the University and for lecturers in Universitas PGRI Palembang Environment.

\section{References}

Arikunto, S. (2013). Prosedur Penelitian Suatu Pendekatan Praktik [Research Procedure A Practical Approach]. Jakarta: Rineka Cipta.

Dewi,W. A. F. (2020). Dampak Covid-19 terhadap Implementasi Pembelajaran Daring di Sekolah Dasar [The Impact of Covid-19 on the Implementation of Online Learning in Elementary Schools]. Edukatif: Jurnal Ilmu Pendidikan, 2(1), 55-61.

Fitriyani, Y., Fauzi, I., \& Sari, M.Z. (2020). Motivasi Belajar Mahasiswa pada Pembelajaran Daring Selama Pandemi Covid-19 [Student Learning Motivation in Online Learning During the Covid-19 Pandemic]. Jurnal Kependidikan: Jurnal Hasil Penelitian dan Kajian Kepustakaan di Bidang Pendidikan, Pengajaran dan Pembelajaran, 6(2), 165-175.

Lestari, N. D., \& Pratiwi, N. (2019). Optimization of Entreprenership Materials to Increase the Students' Learning Result Accounting Education Study Programs Universitas PGRI Palembang [Optimization of Entrepreneurship Materials to Increase the Students' Learning Result Accounting Education Study Programs PGRI University of Palembang]. International Journal of Scientific \& Technology Research, 8(4). 243-247.

Muhibbin, S. (2009). Psikologi Belajar [Learning Psychology]. Jakarta: Rajawali Pers.

Muslich, M. (2009). KTSP Pembelajaran Berbasis Kompetensi dan Kontekstual Panduan bagi Guru, Kepala Lembaga Pendidikan dan Pengawas Lembaga Pendidikan [KTSP Competency-Based and Contextual Learning Guide for 
Teachers, Heads of Educational Institutions and Supervisors of Educational Institutions]. Jakarta: Bumi Aksara.

Naim, N. (2020). Kuliah Daring Dinamika Pembelajaran Ketika Wabah Corona [Online Lecture on Learning Dynamics During the Corona Outbreak]. Tulungagung: IAIN Tulungagung Press.

Nurhayati, F. R., \& Sumbawati, M.S. (2014). Pengembangan E-Portfolio Sebagai Instrumen Penilaian Siswa di SMK Negeri 2 Lamongan [Development of EPortfolio as a Student Assessment Instrument at SMK Negeri 2 Lamongan]. Jurnal Pendidikan Teknik Elektro, 3(1).

Orsini-Jones, Marina \& De, Mausumi. (2007). Research-Led Curricular Inovation: Revisiting Constructionism Viae-Pooetfolio Shared Asset and Webfolio. Procceedings of the $2^{\text {nd }}$ International iPED Conference.

Purwanto, M. N. (2009). Prinsip-Prinsip dan Tekhnik Evaluasi Pengajaran [Teaching Evaluation Principles and Techniques]. Bandung: Remaja Rosdakarya.

Riyanto, H. Y. (2010). Pradigma Baru Pembelajaran Sebagai Referensi bagi Pendidik dalam Implementasi [New Paradigm of Learning as a Reference for Educators in Implementation]. Jakarta: Pranadamedia Group. 